\title{
Modified Peer-written Corrective Feedback on Dialogue Drafting of Twelfth Graders: Focusing on Linguistic Features
}

\author{
Lasti'ah $^{\mathbf{a}, *}$ \\ ${ }^{a}$ SMK Negeri 1 Jombang, Indonesia \\ *Corresponding author. E-mail address: mbaktiek@gmail.com
}

\begin{abstract}
Writing skill is regarded as troublesome for students, leading to errors occurring in the students' writing. Thus, this paper aims to explore the linguistic feature errors in students' writing and how those errors can be minimized by modified peer-written corrective feedback. This study employed a qualitative method with Classroom Action Research (CAR) design through content analysis. The data was collected from vocational high school students' composition of the dialogue draft on the 'offering help' theme. The results reveal that apart from their level of proficiency, students make errors more on linguistic features in their first phase than in their second phase. It is due to the role of modified peer-written corrective feedback given by their peers of different groups. This feedback assists the students in learning their linguistic aspect errors in their writing. In the process of writing, the modified written corrective feedback is imperative to spur students to apply good linguistic features in their writing. In such a case, learning from peer feedback is a good technique since the process becomes the priority rather than the final product. Finally, modified peer-written corrective feedback is effective in enhancing the students' writing skills, particularly in writing dialogue.
\end{abstract}

Keywords: linguistic feature errors, modified peer-written corrective feedback, dialogue draft, offering help

\section{INTRODUCTION}

In Indonesia, both vocational high school and senior high school students have to be proficient in four basic language skills, including listening, speaking, writing, and reading, as stated in the 2013 Curriculum (K-13). Among all of those skills, writing skills are considered troublesome for students (Ariyanti \& Fitriana, 2017). Nunan (2002) stated that writing is the way of expressing and organizing ideas into several written arrangements. Besides, learning to write requires basic awareness with advanced-level sub-skills of preparing and constructing and inferior-level sub-skills of word choice, mechanics, and spelling (Richards \& Renandya, 2002). The idea of teaching writing is to develop students' cognitive skills, which means how to write about what they understand. Teaching writing is also related to motivation. In this case, the use of various methodologies will affect students' writing outcomes. Through writing practice, students will be encouraged to develop writing skills; as a result, students require loads of practice to increase their ability to write written texts (Myles, 2002). Thus, several techniques have been implemented to assist Indonesian high school students in expanding their writing abilities as EFL students. One way is to apply written corrective feedback (hereafter WCF) to students. 
According to Bitchener \& Storch (2016), WCF refers to written feedback to a linguistic error that has been made in the process of writing by the students. WCF is an effort to correct improper usage or serve information regarding the emergence of the error, its reason, and how it might be fixed. Two strategies are applied in the drafting and revising stage: using the instructor's feedback and editing for grammatical errors (Brown \& Lee, 2015). Referring to WCF, the teacher can apply the modified WCF by combining the two aforementioned strategies. In the drafting and revising stages, modified WCF is useful to guide students in producing good writing gradually. Normally, students make errors and mistakes when producing language due to the complexity of language, such as the grammar patterns. It is possible that making errors may assist students to correct the errors made by themselves (Chandler, 2003). Making errors is an inevitable part of learning. Students cannot acquire a language without first making mistakes (Agustina \& Junining, 2015). Through making mistakes, students can learn from their previous errors to improve their language, both spoken and written.

Several studies have examined the topic of WCF, especially in EFL contexts, such as the significance of students' engagement with WCF (Zheng \& Yu, 2018), WCF as the alternatives for enhancing the quality of students' writing (Flora et al., 2020), and the influence of teacher and peer WFC on senior high school students (Elfiyanto \& Fukazawa, 2020). Those previous studies showed the advantages of implementing WCF to better improve students' writing abilities. Besides, one of the previous studies revealed that the students gained positive engagement. Unlike the aforementioned studies, this present study concerns linguistic features implemented as modified WCF. The modification of WCF is the novelty of this research. Modified means that there is a teacher modification on how to do peer-written corrective feedback. Thus, this study possesses two research questions: (1) What linguistic features errors appear in students' writing? and (2) How can these linguistic features errors be minimized with modified peer WCF?

\section{WRITTEN CORRECTIVE FEEDBACK}

Corrective feedback is teachers' response toward the wrongness that students make either in speaking or writing (Pawlak, 2014). The corrective feedback which is used in speaking and writing is completely different. Yet, they have some beneficial effects. In the context of WCF, feedback used can assist students in revising their own reports (Leng, 2014). The directness, clearness, and information of the feedback allow students to revise their writing better. Besides, it has the capacity to inspire students to improve their writing skills and revise their writing drafts (Leng, 2014). Teachers' feedback spurs students to effectively revise their drafts which consequently enhances their motive for being more productive and confident in writing. Last but not least, WCF can boost students' motivation to learn by themselves by considering every feedback from teachers (Leng, 2014).

Some characteristics differentiate WCF from oral corrective feedback. According to Pawlak (2014), there are some characteristics of WCF: (1) the corrective force is usually clear, (2) feedback is only on one's own errors, (3) the feedback is provided only offline (i.e., it is delayed), (4) there is considerable complexity of focus, (5) both input-providing or output-inducting corrective technique is available, (6) the feedback can only be explicit as the intervention is evident, (7) the correction can be conducted by the teacher, (8) the learner who erred or a peer, (9) metalinguistic information is possible, (10) it is mostly didactic, and (11) it is only explicit, declarative, knowledge affected in the main. 


\section{MODIFIED PEER-WRITTEN CORRECTIVE FEEDBACK}

Peer WCF is an alternative to assist the students to enhance their writing skills by giving corrections, opinions, comments, suggestions, and ideas. Through peer WCF, students gain more chances to collaborate and learn from each other. Peer WCF is an assessment type that is done by the students who have the same status. Peer feedback focuses on the qualitative outcome. According to Elfiyanto and Fukazawa (2020), peer feedback can improve Indonesian students' writing skills. Previous studies on peer and teacher WCF detect the precious effects of peer feedback. Peterson (2013) highlighted that the advantages of peer feedback could be seen both from the students who obtain the feedback and the students who provide the feedback. The students are likely more conscious of the qualities of good writing by evaluating their peers' writing. Moreover, peer WCF also expands students' abilities to do self-assessment since they attain knowledge related to the criteria for evaluating their writing (Lundstrom \& Baker, 2009).

This study develops the peer WCF into modified peer WCF. The modification made by the teacher can be seen from the way to do peer WCF. The modifications include several steps as follows: (1) group formation arrangements, (2) corrections are made by another group (odd groups are corrected for even groups and vice versa), (3) before carrying out corrections, students are provided with how to carry out corrections and what aspects to pay attention to, and (4) each group had 2 (two) smart students to avoid the accumulation of smart students in a group. Applying peer WCF in the classroom is useful for several reasons. First, peer WCF can enhance social force on students to do a great job (Gielen et al., 2010). Second, studies on higher education denote that the students often realize peer WCF as comprehensible and useful since they feel that their peers are in a similar condition. Finally, peer WCF reaches students more quickly. Since teacher WCF is frequently postponed after collecting an assignment and is occasionally not given until the topic has altered, rough feedback from the peers displayed in a direct way might have a much greater impact than perfect feedback from an instructor in the next four weeks (Gibbs and Samson, 2004, as cited in Elfiyanto \& Fukazawa, 2020).

\section{ERROR AND MISTAKE}

Making mistakes is unavoidable since it is an ordinary thing that humans do. When practicing a skill, such as swimming, driving a car, or using a language, students often make mistakes in their early learning (Al-Sobhi, 2019). However, these errors decrease gradually as the students attain more experience and utilize the necessary knowledge. Brown and Lee (2015) noted that first mistakes gradually diminish as you learn from them. Within the process of learning a language, errors have been explained in a different way by some experts. For example, Ferris (2011) states that errors refer to syntactic, lexical forms, and morphological that do not conform to the target language rules. This statement is in line with Corder (1981, as cited in Al-Sobhi, 2019), who elucidated errors as systematic defects caused by the lack of linguistic competence of the students. Therefore, students' errors are influenced by the lack of linguistic knowledge and awareness rather than performance.

In terms of error analysis, the idea of error has a special meaning, which is not the same as 'mistake.' Corder (1981, as cited in Al-Sobhi, 2019) explicitly differentiates between 'error' and 'mistake.' An error is a 'failure in competence' while a mistake is a 'failure in performance.' Further, unlike mistakes, errors are more systematic since they disclose the linguistic knowledge that the language learner underlies. Yet, mistakes are non-systematic; 
for example, students do not make mistakes due to a lack of competence instead of performance failures due to their external and internal circumstances when they speak or write. Such students' mistakes happen because of physical states such as fatigue, memory lapses, and psychological states such as strong emotions (Corder, 1981, as cited in Al-Sobhi, 2019). On the other hand, they happen when students feel nervous, stressed, anxious, tired, etc. From the above differences, students' slips of tongue or pen were inspected for 'mistakes' if they were self-correcting, without external help. According to James (2013), self-correction plays a significant role in differentiating mistakes from errors. In addition, students' mistakes and errors differ in the case of intentionality. James (2013) shows that the intention of the students is crucial to decide whether the student made a mistake or an error. He described that students' errors were not made intentionally while mistakes were made.

\section{SUBCATEGORIES OF GRAMMATICAL ERROR}

Since error analysis is the study of students' errors, either written or oral production, it offers a particular description of the error field. James (2013) proposed some taxonomies of errors, such as syntax (phrases, clauses, and word order), grammar (articles, prepositions, verb forms, etc.), lexicon/semantics (word meaning and choice), phonology (pronunciation), discourse (style), and orthography (spelling, capitalization, and punctuation). This study only concerns grammatical errors, lexicon/semantics, and orthography. In grammatical errors, James (2013) classified them into seven categories: pronouns, subject/verb agreement, articles, prepositions, verb forms, conjunctions, and singular/plural forms. The second taxonomy of errors is lexico-semantic. It happens when students cannot choose the appropriate word for a specific context, such as choosing learns for teaches, aloud for allowed, and clocks for hours. For example, this shop is open 24 clocks, Mr. Al-Ahmad learns us grammar, and kids are not aloud to enter the museum. The third taxonomy of errors is orthographic. It happens due to the absence of one-to-one correspondence between the English graphemes and phonemes, and vice versa. Hence, English spelling is recurrently described as challenging for EFL students. For example, the phoneme/k/can be characterized in a different way as in school, kind, car, back, queen, and account.

\section{METHOD}

This study employed Classroom Action Research (CAR) design with content analysis. Krippendoff (2018) stated that content analysis is utilized to analyze verbal communication found in textbooks, lectures, informal teacher-pupil interaction, the written composition of pupils, and other sources. It suits the data source, which is in the form of students' writing composition, dialogue draft. This study utilized a qualitative approach since the data are in the form of words, phrases, and clauses (Creswell \& Creswell, 2018). Since descriptive research was employed, this study investigates the linguistic features errors that appear in students' writing and how these linguistic feature errors can be minimized with modified WCF. This research was conducted at one of the vocational high schools in Jombang. The participants were 36 (thirty six) students of the $12^{\text {th }}$ graders who are in the same class with heterogeneous English proficiency. They are divided into 9 (nine) groups under the dialogue writing task on the 'offering help' theme. Their dialogue writing drafts were analyzed to examine whether the modified WCF given by their peers could assist them in reducing their linguistic feature errors in their writing. 
This CAR was conducted in two cycles by using the action research procedures: (1) planning the action, (2) implementing the action, (3) observing the action, and (4) reflecting the action (Young et al., 2010). In this study, the grammatical errors produced by students in their first and second writing were classified based on their peer WCF. It was to know the grammatical errors students produced in their report draft. Then, the first and second writing report drafts are analyzed. Both first and second report drafts of each student are compared to know whether the peer WCF implemented by their teacher can minimize grammatical errors in their report draft. In this case, the teacher as the researcher employed the modification on how to do peer WCF. The modifications involve the following steps: (1) group formation arrangements, (2) corrections are made by another group (odd groups are corrected for even groups and vice versa), (3) before carrying out corrections, students are provided with how to carry out corrections and what aspects to pay attention to, and (4) each group had 2 (two) smart students to avoid the accumulation of smart students in a group.

\section{FINDINGS AND DISCUSSION}

This study employed Classroom Action Research (CAR) design with content analysis. Two major theories proposed by James (2013) and Elfiyanto (2020) were used in this study. This section presents the results of the first research question, which classified errors into several taxonomies, such as grammar, lexicon/semantics, and orthography. Then, it is followed by serving the results of the second question, which discusses how to minimize errors with modified peer WCF. In addition, the comparison between the first writing draft and second writing draft is deliberated.

\section{THE IMPROVEMENT OF STUDENTS' WRITING SKILLS AFTER MODIFIED PEER WCF}

This section reveals the results of the first and second writing draft to see the improvement of students' writing skills. The results detect a few errors compared to the first writing draft in terms of grammar, lexicon/semantic, and orthography errors. Below is the table that shows the percentages of students' grammatical errors after applying modified peer WCF.

Table 1. The percentages of students' grammatical errors after applying modified peer WCF

\begin{tabular}{lcccc}
\hline \multirow{2}{*}{ Category } & \multicolumn{2}{c}{ First Writing Draft } & \multicolumn{2}{c}{ Second Writing Draft } \\
\cline { 2 - 5 } & Frequency & Percentage & Frequency & Percentage \\
\hline Grammar & 3 & $17 \%$ & 2 & $29 \%$ \\
Lexicon/semantics & 4 & $22 \%$ & 1 & $14 \%$ \\
Orthography & 11 & $61 \%$ & 4 & $57 \%$ \\
\hline Total & $\mathbf{1 8}$ & $\mathbf{1 0 0 \%}$ & $\mathbf{7}$ & $\mathbf{1 0 0 \%}$ \\
\hline
\end{tabular}

The first writing draft displayed that the high percentage is orthography with the frequency of 11 (eleven) or 61\%. It is in line with a study by Ratnaningsih \& Azizah (2019), which stated that orthography (especially capitalization) gained the highest percentage, with the total error being 60 or $14,67 \%$. The second position is the lexicon/semantics category with the frequency of 4 (four) or $22 \%$. The low percentage is the grammar category with the frequency of 3 (three) or $17 \%$. Meanwhile, the second writing draft presented a lower frequency of error than the frequency of the first writing draft. In total, the frequency of error in the second writing draft is 7 (seven). It includes orthography with the frequency of error of 4 or $57 \%$, grammar with the frequency of error of 2 or $17 \%$, and lexicon/semantics with the 
frequency of error is 1 or $14 \%$. In short, there is an improvement in students' writing skills after applying modified peer WCF. This finding is in harmony with Flora et al. (2020) and Elfiyanto \& Fukazawa (2020), which found that peer WCF enhances the students' writing ability. Yet, those findings contrast with the study done by Andrade \& Du (2007) and Rana \& Peerven (2013), which revealed that peer WCF does not contribute or improve students' writing ability.

After classifying and totaling the percentage of each error, it presents the details of examples from each category in the first writing draft. The researcher gained the results from the students' dialogue writing task on the 'offering help' theme. After gathering the data from the students, the data were examined and highlighted on the errors made in the students' dialogue draft. It focuses on 3 (three) types of errors, involving grammar, lexicon/semantics, and orthography. The evidence of each type of error is highlighted as follows:

\section{GRAMMAR}

The first type of error made by the vocational high school students in $12^{\text {th }}$ grade was grammar. This is in accordance with Asfiyati (2021) which found that grammatical errors frequently occur in students' writing. Basically, the grammar error is categorized into seven types: pronouns, subject/verb agreement, articles, prepositions, verb forms, conjunctions, and singular/plural forms. Several types of grammar errors are found in the dialogue draft writing. Below is one of the student's grammar error examples in verb forms:

Data 1

Student 1: I want to check the eyes. Is a doctor there?

Student 2: Sorry. The doctor didn't come today.

According to the first data, it was clear that the students made incorrect verb forms related to the tenses used in the dialogue. Since no specific time indicates past activities, the word didn't is inappropriate to be employed. The correct verb for this situation is doesn't, which denotes present tense. Another example from student's grammar error could be seen as follows:

Data 2

Student 1: Ice cream. Do you have ice cream?

Student 2: I have one on the fridge. Do you want me to get it for you?

Based on the above excerpt, it obviously shows that a student's grammar error occurs in the use of prepositions. It could be seen that student 2 omitted the proper rules of the preposition. The correct preposition in the sentence should be in the fridge since the ice cream is inside the fridge, not above the fridge. 


\section{LEXICON/SEMANTICS}

The second type of error done by students was lexicon/semantics. Students expect feedback from the teachers related to global and local errors (Elfiyanto \& Fukazawa, 2020). Global errors include purposes, organization, and content, while local errors include grammar, sentence structure, and word choice. Theoretically, lexicon/semantics error is distinguished into two types: word choice and word meaning. The example of a student's lexicon/semantics error could be seen as below:

Data 3

Student 1: What are you doing?

Student 2: I'm making report, but I can.

In data 3, the student's lexicon/semantics error is indicated through the word choice from student 2. In this case, student 1 asked about the current activity of student 2. Yet, the response of student 2 is not coherent. The first sentence denotes that student 2 is making a report, but the next sentence shows inappropriate words. The use of conjunction but refers to the contradiction situation. Hence, the correct word in the sentence should be negative I'm making report, but I can't. Another example from a student's lexicon/semantics error is displayed as follows:

\section{Data 4}

Student 1: Good morning, can I help you?

Student 2: I want to check the eyes. Is a doctor there?

From data 4, lexicon/semantics error made by students is seen through word choice. To respond to student 1 , student 2 wrote $I$ want to check the eyes in the dialogue writing draft. This sentence is quite ambiguous in terms of whose eyes and what is being complained about. Therefore, the sentence should be changed to I have problems with my eyes.

\section{ORTHOGRAPHY}

The last type of error made by students was orthography. In this study, orthography gains the highest number of frequencies compared to other categories. It is in harmony with Ratnaningsih \& Azizah (2019), which revealed that orthography (especially capitalization) obtained the highest percentage. There are 3 (three) categories of orthography error, namely spelling, capitalization, and punctuation. The following is an example of each student's orthography error.

\section{Data 5}

Student 1: Do you have something to drink? I'm so tired and thristy. Student 2: I have lots of drink. What do you want?

The above excerpt noticeably displays that a student's orthography error has occurred in the spelling case. The students' error is also indicated through the use of wrong spelling (Rana \& Peerven, 2013). From the data, the student wrote thristy instead of thirsty (the correct one). Another evidence which shows student's orthography error is presented as follows:

Data 6

Student 1: Of course, Emil. 
Student 2: Thank you, cin.

According to the sixth data, it was apparent that the students made orthography errors, especially in the use of capitalization. The students often wrote the person's name or after full stop by using small letters (Ratnaningsih \& Azizah, 2019). As in the dialogue written by student 2, the word cin refers to people's names. Consequently, the $c$ letter should be changed into capitalized letter $C$. Another proof from student's orthography error, particularly punctuation case, could be displayed as follows:

\section{Data 7}

Student 1: What kind of gifts would you like to find?

Student 2: I dont know, maybe a watch?

In data 7, the student's orthography error is indicated through the sentence written by student 2. In this case, student 2 composed the sentence without considering the punctuation rules. The students often make some errors in using an apostrophe ('), comma (,) and full stop (.) (Ratnaningsih \& Azizah, 2019). It could be seen that the word dont does not provide apostrophe (') between $n$ and $t$. Meanwhile, the sentence maybe a watch employs the question mark (?) at the end of the sentence instead of using full stop (.). It is an inappropriate mark to be used since the sentence is included in an affirmative sentence instead of an interrogative sentence. Hence, the correct sentence should be I don't know, maybe a watch.

There are 3 (three) types of errors found in dialogue writing drafts: grammar, lexicon/semantics, and orthography. The highest frequency of errors made by the students both in first and second writing is orthography. The first phase detects a lot of errors made by students in dialogue writing drafts. However, there is an improvement in students' writing quality which could be seen through the second phase of dialogue draft writing. These errors can be minimized by applying modified peer WCF. Hence, it is believed that modified peer WCF has a significant role in improving the quality of the student's writing ability, especially in writing dialogue.

\section{CONCLUSION}

This research's results point out that modified peer WCF effectively minimizes student errors in writing skills, especially in dialogue writing drafts. It is supported by the data found in the first phase compared to the second phase of the dialogue writing draft. The first phase of the dialogue writing draft detected several types of errors, while in the second phase of the dialogue writing draft, it only found a few errors. There were only 3 (three) out of 7 (seven) error types involving grammar, lexicon/semantics, and orthography. The orthography errors take the highest position of errors made by students both in the first and second phases. Thus, these errors can be minimized by applying modified peer WCF. It is believed that modified peer WCF has an important role in enhancing the quality of the students' writing ability, especially in writing dialogue. 


\section{REFERENCES}

Agustina, V., \& Junining, E. (2015). Error analysis in the travel writing made by the students of English study program. Journal of English Education and Linguistics Studies, 2(1), $1-28$.

Al-Sobhi, B. M. S. (2019). The Nitty-gritty of language learners' errors - Contrastive analysis, error analysis and interlanguage. International Journal of Education and Literacy Studies, 7(2), 49-60. https://doi.org/10.7575/aiac.ijels.v.7n.3p.49

Andrade, H., \& Du, Y. (2007). Student responses to criteria-referenced self-assessment. Assessment \& Evaluation in Higher Education, 32(2), 159-181.

Ariyanti, A., \& Fitriana, R. (2017). EFL students' difficulties and needs in essay writing. International Conference on Teacher Training and Education (ICTTE), 158, 111-121. https://doi.org/10.2991/ictte-17.2017.4

Asfiyati, N. (2021). Analyzing students' grammatical errors in writing narrative text at second semester students of UNISMA. Jurnal Penelitian, Pendidikan, Dan Pembelajaran, 16(26).

Bitchener, J., \& Storch, N. (2016). Written corrective feedback for L2 development. Multilingual Matters.

Brown, H. D., \& Lee, H. (2015). Teaching by principles: An interactive approach to language pedagogy (4th ed). Pearson Education Inc.

Chandler, J. (2003). The efficacy of various kinds of error feedback for improvement in the accuracy and fluency of L2 student writing. Journal of Second Language Writing, 12(3), 267-296. https://doi.org/10.1016/S1060-3743(03)00038-9

Creswell, J. W., \& Creswell, J. D. (2018). Research design: Qualitative, quantitative, and mixed methods approaches, (5th ed). Los Angeles: SAGE.

Elfiyanto, S., \& Fukazawa, S. (2020). Effect of teacher and peer written corrective feedback on writing components in EFL classrooms. JEES (Journal of English Educators Society), 5(2), 185-191. https://doi.org/10.21070/jees.v5i2.826

Ferris, D. (2011). Treatment of error in second language student writing. University of Michigan Press.

Flora, F., Farhana, S., Nisa, K., \& Mentari, R. (2020). The proportion of Peer Corrective Feedback (PCF) on writing aspects: Are they really effective? In A. for C. Machinery (Ed.), The 4th International Conference on Learning Innovation and Quality Education Surakarta. https://doi.org/10.1145/3452144.3453835

Gielen, S., Tops, L., Dochy, F., Onghena, P., \& Smeets, S. (2010). A comparative study of peer and teacher feedback and of various peer feedback forms in a secondary school writing curriculum. British Educational Research Journal, 36(1), 143-162. https://doi.org/10.1080/01411920902894070

James, C. (2013). Errors in language learning and use: Exploring error analysis. Routledge.

Krippendoff, K. (2018). Content analysis: An introduction its methodology. Sage publications.

Leng, K. T. P. (2014). An analysis of written feedback on ESL students' writing. Procedia Social and Behavioral Sciences, 123, 389-397. https://doi.org/10.1016/j.sbspro.2014.01.1437

Lundstrom, K., \& Baker, W. (2009). To give is better than to receive: The benefits of peer review to the reviewer's own writing. Journal of Second Language Writing, 18(1), 3043. https://doi.org/10.1016/j.jslw.2008.06.002

Myles, J. (2002). Second language writing and research: The writing process and error 
analysis in student texts. TESL-EJ, 6(2), 1-20.

Nunan, D. (2002). Second language acquisition. In The Cambridge guide to teaching English to speakers of other languages (pp. 87-92). Cambridge University Press. https://doi.org/10.15864/ijelts.1407

Pawlak, M. (2014). Error correction in the foreign language classroom: Reconsidering the issues. Springer Science \& Business Media.

Peterson, S. S. (2013). Peer feedback on writing: An assessment for learning. Research for Teacher.

Rana, A. M. K., \& Peerven, U. (2013). Motivating students through self-correction. Educational Research International, 2(2), 192-196.

Ratnaningsih, S., \& Azizah, A. (2019). Error analysis in the descriptive text writing of vocational high school students. Dinamika Ilmu, 19(1), 175-186. https://doi.org/10.21093/di.v19i1.1364

Richards, J. C., \& Renandya, W. A. (2002). Methodology in language teaching: An anthology of current practice. Cambridge university press.

Young, M. R., Rapp, E., \& Murphy, J. W. (2010). Action research: Enhancing classroom practice and fulfilling educational responsibilities. Journal of Instructional Pedagogies Action, 1-10.

Zheng, Y., \& Yu, S. (2018). Student engagement with teacher written corrective feedback in EFL writing: A case study of Chinese lower-proficiency students. Assessing Writing, 37, 13-24. https://doi.org/10.1016/j.asw.2018.03.001 